\title{
Occurrence of Brettanomyces/Dekkera in Brazilian red wines and its correlation with ethylphenols
}

\author{
Larissa Dias de Ávila ${ }^{1}$, Marco Antônio Záchia Ayub ${ }^{2}$ \\ ${ }^{1}$ Instituto Federal de Educação, Ciência e Tecnologia do Rio Grande do Sul, Bento Gonçalves, RS, Brazil. \\ ${ }^{2}$ Instituto de Tecnologia e Ciência de Alimentos, Universidade Federal do Rio Grande do Sul, \\ Porto Alegre, RS, Brazil.
}

Submitted: May 24, 2011; Approved: July 2, 2012.

\begin{abstract}
The yeast Brettanomyces/Dekkera can cause important spoilage in wines, with the production of ethylphenols and other off-flavor compounds. This study aimed at determining the presence of this yeast and the ethylphenols produced by them in Brazilian red wines, establishing their relationship with other chemical characteristics. Isolates of Brettanomyces/Dekkera were quantified by plating 126 samples of dry red wine in selective culture medium, while ethylphenols were analyzed by solid phase extraction and GC/FID. Free and total $\mathrm{SO}_{2}$, alcohol, total dry extract, residual sugar, total and volatile acidity, and $\mathrm{pH}$ were also determined. Brettanomyces/Dekkera was present in $27 \%$ of samples. Ethylphenols were detected in most samples, with amounts higher than the threshold limit of $426 \mu \mathrm{g} / \mathrm{L}$ found in $46.03 \%$ of samples. The majority of wine samples showed inadequate levels of $\mathrm{SO}_{2}$ and residual sugars, facts that might facilitate microbial spoilage. The passage in barrels and the grape varieties (Cabernet Sauvignon and Merlot), did not show any influence on the levels of contamination or ethylphenols contents. The prevalence of Brettanomyces/Dekkera and the concentrations of ethylphenols were high considering the sensory impact they can cause. The growth of Brettanomyces/Dekkera was dependent on the levels of $\mathrm{SO}_{2}$ and alcohol of wines. Knowledge of the contamination, the presence of ethylphenols, and their relationship with the chemical characteristics of wines can entice effective measures to prevent Brettanomyces/Dekkera and contribute to improve the general quality of Brazilian red wines.
\end{abstract}

Key words: Brettanomyces, Dekkera, 4-ethylphenol, 4-ethylguaiacol, wine.

\section{Introduction}

Wines are subject to chemical and microbiological spoilage and yeasts of the genus Brettanomyces or its teleomorph Dekkera can be important causes of these problems, especially in red wines, with the production of ethylphenols and the formation of off-flavors, which are generally described as phenolic, medicinal, or animal (horse sweat, stable and leather) (Chatonnet et al., 1990). Ethylphenols, 4-ethylphenol, and 4-ethylguaiacol, are formed from the transformation of $p$-coumaric and ferulic acids, naturally present in wines. These transformations occur by a chain reaction of cinnamate decarboxylase generating vinylphenols, and then ethylphenols via vinylphenol reductase (He- resztyn, 1986; Lauritsen et al., 1991; Chatonnet et al., 1992). Spoilage sets up after the fermentation, usually during maturation in barrels (Chatonnet et al., 1990, 1992). The risk of microbial degradation of the wines is particularly high in wood barrels, due to the difficulty of cleaning and disinfection (Malfeito-Ferreira et al., 2004). However, the growth of Brettanomyces/Dekkera and the formation of ethylphenols can also occur in concrete or stainless steel tanks (Rodrigues, et al., 2001), and even in bottles (PérezPrieto et al., 2003).

Although all wines are susceptible to contaminations, some factors will increase this risk, for instance, when using very ripe grapes, with high contents of phenolic acids and high $\mathrm{pH}$, long maceration times and difficult fermenta-

Send correspondence to M.A.Z. Ayub. Instituto de Tecnologia e Ciência de Alimentos, Universidade Federal do Rio Grande do Sul, Bento Gonçalves 9500, Porto Alegre, RS, Brazil. E-mail: mazayub@ufrgs.br. 
tion, which will necessarily delay the addition of sulphite (Gerbaux et al., 2000; Pérez-Prieto et al., 2003). Higher temperatures and $\mathrm{pH}$ (Dias et al., 2003; Romano et al., 2008), dissolved oxygen (Ciani and Ferraro, 1997), and residual sugar (Chatonnet et al., 1995), as well as the lower concentration of ethanol (Gerbaux et al., 2000) and sulphur dioxide (Chatonnet et al., 1992, 1993; Gerbaux et al., 2002; Barata et al., 2008), are other factors involved with the growth of Brettanomyces/Dekkera and the increase of ethylphenols in wines.

Brettanomyces/Dekkera can use acetic acid (Gerós et al., 2000) and ethanol (Dias et al., 2003) as the sole carbon sources, but in the presence of carbon sources commonly found in wines this metabolism is blocked (Vigentini, et al., 2008). Therefore, this yeast will grow in wines, taking advantage of even small amounts of residual sugars such as glucose, fructose, arabinose and trehalose (Chatonnet et al., 1995), arginine (Joseph and Bisson, 2004), and organic acids (Vigentini et al., 2008). Theoretically, concentrations of hexoses of $100 \mathrm{mg} / \mathrm{L}$ can support populations of Brettanomyces/Dekkera as large as $10^{7}$ cells $/ \mathrm{mL}$ (Smith, 1998). Since the production of characteristic off-flavors of Brettanomyces/Dekkera can start appearing in wines when its population is as low as $10^{2}$ or $10^{3}$ cells $/ \mathrm{mL}$, this becomes a major problem for the wine industry (Henick-Kling et al., 2000; Fugelsang and Zoecklein, 2003). Wine spoilage caused by Brettanomyces/Dekkera has been reported worldwide (Heresztyn, 1986; Chatonnet et al., 1992; Heimoff, 1996; Ibeas et al., 1996; Fugelsang and Zoecklein, 2003). Brazil is becoming an important wine producer and exporter, with very typified products, and its industry is well known for its good technology, although climate conditions will frequently pose some challenges for grape quality. Little is known on the presence of Brettanomyces/Dekkera in Brazilian wines and its possible effects on wine quality. In this context, the main objective of this study was to determine the presence of these yeasts and the related ethylphenols in samples of red wines, and try to establish a relationship with other chemical characteristics of these wines, thus contributing to improve the general quality of this important product.

\section{Materials and Methods}

\section{Chemicals}

Unless otherwise stated, all chemicals were of analytical grade and purchased from Sigma-Aldrich (St. Louis, USA).

\section{Wine samples}

A total of 126 samples of 63 dry red wines were selected for this research. Wines were collected from 26 wineries located in the largest and most traditional wine region of southern Brazil, in the hills of the cities of Bento Gonçalves and Farroupilha (RS, latitude $29^{\circ} \mathrm{S}$, longitude $51^{\circ} \mathrm{W}$ ). Samples were arranged as 54 of Cabernet Sauvignon and 63 of Merlot, while 7 were of other red varieties, and 2 were assemblage of the mentioned varieties, distributed between 2004 and 2005 vintages. Microbiological analyses were performed immediately after the opening of the bottles; the remaining wine was frozen for later chemical analysis.

\section{Culture medium and microbiological techniques}

A selective and differential medium for Brettanomyces/Dekkera (DBDM) developed by Rodrigues et al. (2001) was used in this research, with some modifications. Its basic composition is (in $\mathrm{g} / \mathrm{L}$ ): Yeast Nitrogen Base, 6.7; ethanol, 60; $p$-coumaric acid, 0.1; cycloheximide, 0.01; bromocresol green, 0.022; agar, 20 (pH 5.4). The medium was modified by the addition of glucose $(5 \mathrm{~g} / \mathrm{L})$ and chloramphenicol $(0.1 \mathrm{~g} / \mathrm{L})$. This medium inhibits the growth of other yeast species due to the presence of cycloheximide. In addition, the medium allows the differentiation of the Brettanomyces/Dekkera strains by their characteristic production of ethylphenols (off-flavors) from $p$-coumaric acid, the acidification, and the long incubation time required. Addition of glucose was to improve the recovery of Brettanomyces/Dekkera, and chloramphenicol, to prevent growth of bacteria.

The medium was sterilized by filtration and the agar was autoclaved separately. Varying volumes of wine were plated in agar DBDM; $0.1 \mathrm{~mL}$ was directly spread onto plates, while volumes of 1 and $20 \mathrm{~mL}$ were filtered through a $0.45 \mu \mathrm{m}$ membrane that was placed over the medium. Colonies were counted after 3 and 14 days of incubation at $28^{\circ} \mathrm{C}$.

\section{Determination of 4-ethylphenol and 4-ethylguaiacol}

Solid phase extraction (SPE) was performed using polystyrene-divinylbenzene cartridges Lichrolut-EN $200 \mathrm{mg}$ (Merck, Darmstadt, Germany). The cartridges were conditioned with $4 \mathrm{~mL}$ of dichloromethane, $4 \mathrm{~mL}$ of methanol, and $4 \mathrm{~mL}$ of ethanol $12 \%$ (volume fraction). Subsequently, $50 \mathrm{~mL}$ of filtered wine containing $5 \mathrm{mg} / \mathrm{L}$ of an internal standard (3,4-dimethylphenol) were passed through the SPE cartridge at a flow rate of $2 \mathrm{~mL} / \mathrm{min}$. The sorbent was washed with $3 \mathrm{~mL}$ of ultra-pure water, dried-up by airflow for 3 min Finally, ethylphenols were eluted with $1.4 \mathrm{~mL}$ dichloromethane. The eluate was kept frozen until analysis. The recovery efficiencies of 4-ethylphenol and 4-ethylguaiacol using this methodology were always around $100 \%$.

A gas chromatograph (CG-14B Shimadzu, Tokyo, Japan) equipped with flame ionization (FID) was used to determine ethylphenols. The analyses were performed by injecting $\mu$ Lof the eluate in split mode (ratio $1: 10,250^{\circ} \mathrm{C}$ ) into a DB-WAX column $(60 \mathrm{~m} \times 0.25 \mathrm{~mm}$ i.d. $\mathrm{x} 0.25 \mu \mathrm{m}$ film thickness; Agilent J\&W, Folsom, USA). The carrier gas was $\mathrm{H}_{2}$ at a flow of $1 \mathrm{~mL} / \mathrm{min}$. The temperature program 
was as follows: $50{ }^{\circ} \mathrm{C}$ for $1 \mathrm{~min}$, first ramp to $180{ }^{\circ} \mathrm{C}$ at $10{ }^{\circ} \mathrm{C} / \mathrm{min}$, second ramp to $205^{\circ} \mathrm{C}$ at $3{ }^{\circ} \mathrm{C} / \mathrm{min}$, third ramp to $215^{\circ} \mathrm{C}$ at $2{ }^{\circ} \mathrm{C} / \mathrm{min}$, fourth ramp to $230^{\circ} \mathrm{C}$ at $15{ }^{\circ} \mathrm{C} / \mathrm{min}$, and then kept at $230^{\circ} \mathrm{C}$ for $30 \mathrm{~min}$. The detector was kept at $250{ }^{\circ} \mathrm{C}$.

\section{General Analytical procedures}

Free $\mathrm{SO}_{2}$ in wine samples was analyzed using an Oenological Analyzer (Quick, Gibertini, Milano, Italy) equipped with $\mathrm{SO}_{2}$ bubble, following titration with $0.02 \mathrm{~N}$ iodine solution. Total $\mathrm{SO}_{2}$, was analyzed by steam distillation in an Oenochemical Distilling Unit (DEE, Gibertini, Milano, Italy) following titration with $0.02 \mathrm{~N}$ iodine solution. The ethanol content, density and total dry extract were determined using Alcolyzer Wine and density meter (DMA 4500, Anton Paar ${ }^{\circledR}$ GmbH, Graz, Austria). Finally, residual sugar, total and volatile acidity, and $\mathrm{pH}$ were determined by infrared spectroscopy using a WineScan ${ }^{\mathrm{TM}}$ FT120 (FOSS, Denmark).

\section{Statistical analysis}

Spearman correlation $\left(r_{s}\right)$ analysis was used in order to correlate yeast cell numbers, concentration of ethylphenols and other chemical parameters of wines. Student's t-test was used to compare the average of results. The statistical analysis was performed using SPSS 16.0 software (SPSS Inc., USA).

\section{Results and Discussion}

\section{Prevalence of Brettanomyces/Dekkera in wine samples and concentration of ethylphenols}

Results for the investigation of the presence of Brettanomyces/Dekkera in wine are shown in Table 1. Thirty-four $(27 \%)$ samples produced typical colonies of this yeast when they were plated onto the DBDM medium: colonies yellow to olive green, acidification of the medium, phenolic flavour and slow growth, reaching up to $2.25 \times 10^{3}$ $\mathrm{CFU} / \mathrm{mL}$. These values are similar to results reported by Gerbaux et al. (2000) and Rodrigues et al. (2001), in which the presence of Brettanomyces was found in 25 and $57 \%$ of a total of 44 and 88 samples of Pinot Noir wines from the Burgundy region and Portuguese wines, respectively, con- taining up to $2.5 \times 10^{3} \mathrm{CFU} / \mathrm{mL}$. This high CFU counting is of great concern for the wine industry, because it is very difficult to control Brettanomyces/Dekkera in these environments. Concerning the samples amount of ethylphenols, they were present in high percentages, above the preference thresholds for these compounds, considering the sensory impact they may cause, but were within the range reported by others authors (Table 1). Chatonnet et al. (1992) have established the limit preference thresholds of $620 \mu \mathrm{g} / \mathrm{L}$ for 4-ethylphenol, $140 \mu \mathrm{g} / \mathrm{L}$ for 4-ethylguaiacol and $426 \mu \mathrm{g} / \mathrm{L}$ to a 10:1 mixture of 4-ethylphenol and 4-ethylguaiacol. Average and maximal values (in $\mu \mathrm{g} / \mathrm{L}$ ) found in previous studies reached up to 1,164 and 6,047 for 4-ethylphenol, and 99 and 1,561 for 4-ethylguaiacol, respectively (Chatonnet et al., 1992; Gerbaux et al., 2000; Pollnitz et al., 2000; Rodrigues et al., 2001; López et al., 2002; Henschke et al., 2004; Nikfardjam et al., 2009; Romano et al., 2009).

The yeast counts correlated $(\mathrm{p}<0.01)$ with concentrations of 4-ethylphenol $\left(r_{s}=0.397\right)$ and 4-ethylguaiacol $\left(r_{s}=0.318\right)$ (Figure 1a). However, the prevalence of ethylphenols was higher than that of Brettanomyces/Dekkera, similarly observed by Rodrigues et al. (2001). One possibility for this unusual result might reside in the fact that ethylphenols were produced in an early stage in the wine, previously of procedures that would reduce the microbial load for bottling or, for the same reasons, the yeast cells could be in a non-cultivable state (Millet and LonvaudFunel, 2000). Another possibility could be the action of other yeast species such as Pichia and Candida, or bacteria such as Lactobacillus, which can produce ethylphenols (Edlin et al., 1995; Chatonnet et al., 1995, 1997; Dias et al., 2003; Couto et al., 2006; Rivas et al., 2009).

Surprisingly, the yeast counts showed variations among different bottles of the same wine, suggesting that each bottle should be individually evaluated. Thus, it would not be strictly correct to use the average of counts of different bottles of the same wine to express the presence of Brettanomyces/Dekkera. These variations among bottles were also observed and reported by other authors (Di Stefano, 1985; Chatonnet et al., 1993). The different environmental conditions of each fermentation tank, barrel or bottle, or different microbial loads of contaminated materials

Table 1 - Determination of Brettanomyces/Dekkera (CFU/mL), 4-ethylphenol (4-EP), and 4-ethylguaiacol (4-EG), in $\mu \mathrm{g} / \mathrm{L}$, and percentages above the preference threshold of 126 samples of Brazilian red wines.

\begin{tabular}{lcccc}
\hline & Brett/Dekkera & 4-ethylphenol & 4-ethylguaiacol & Ratio 4-EP/4-EG \\
\hline Minimal & 0 & 0 & 0 & 1.29 \\
Maximal & 2,250 & $3,819.65$ & 259.67 & 21.98 \\
Average \pm SD & $76.03 \pm 314.42$ & $593.40 \pm 694.62$ & $65.24 \pm 52.69$ & $7.77 \pm 4.56$ \\
CV (\%) & 413.56 & 117.05 & 80.77 & 53.69 \\
Above the preference threshold (\%) & & 34.92 & 7.93 & $46.03 *$ \\
\hline
\end{tabular}

$\mathrm{CV}$, coefficient of variation; * refers to the mixture (10:1) of 4-EP and 4-EG. 

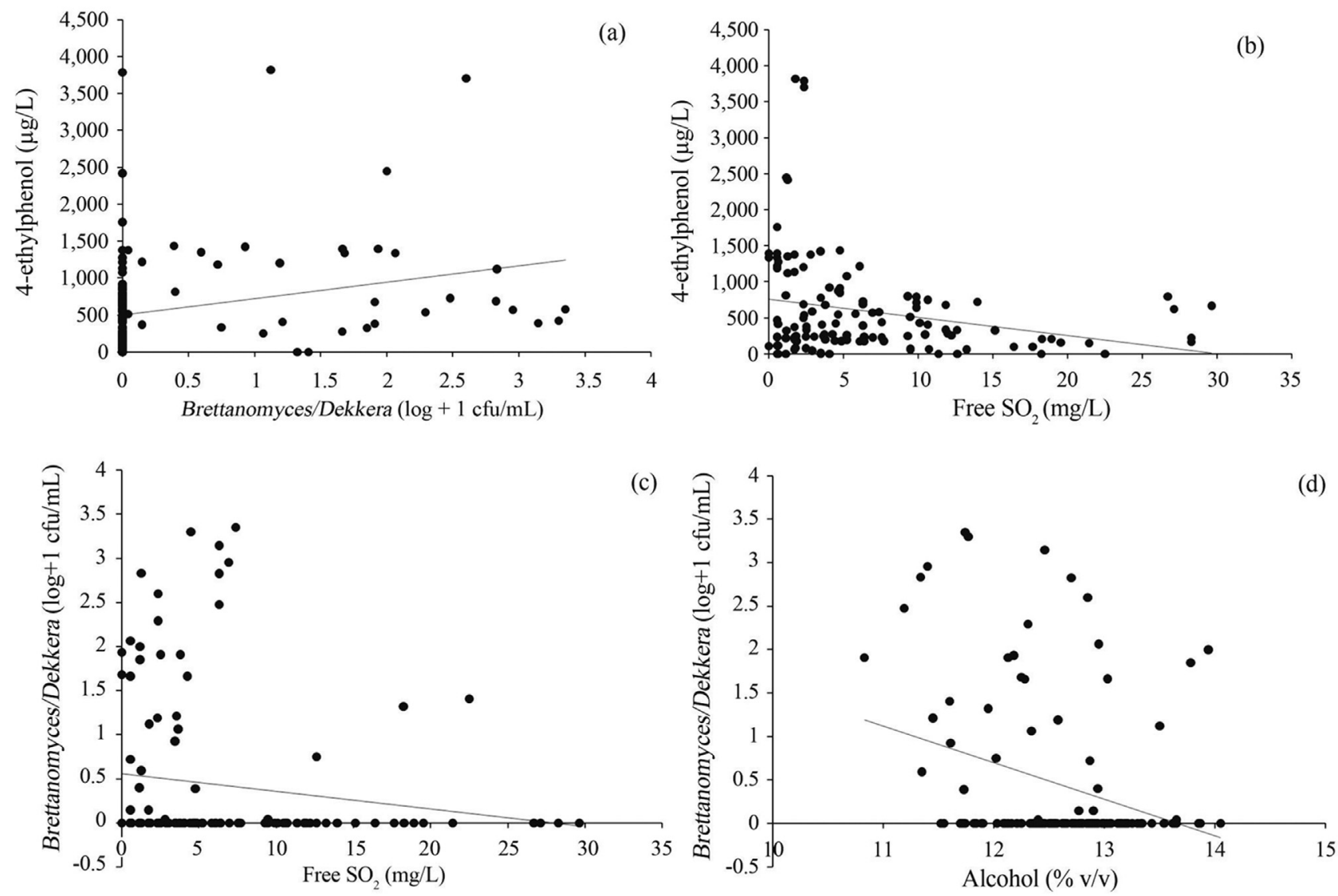

Figure 1 - Correlation between 4-ethylphenol and Brettanomyces/Dekkera counts (a), and free $\mathrm{SO}_{2}$ (b); correlation between Brettanomyces/Dekkera counts and free $\mathrm{SO}_{2}(\mathrm{c})$, and alcohol (d).

and equipment at the beginning of the bottling process may be responsible for these variations, stressing the importance of careful processing to avoid these problems.

The concentrations of 4-ethylphenol and 4-ethylguaiacol were statistically correlated $\left(r_{s}=0.860\right)$, and the ratio between them varied from 1.37 to 21.98 , which is close to the range (1.6 to 38) found by Pollnitz et al. (2000) and Henschke et al. (2004). According to these authors, this ratio depends on the relative abundance of precursors, which is dependent on the geographic region and grape variety. Romano et al. (2008) observed the ratio of 1:1 when they used a synthetic medium containing equal concentrations of $p$-coumaric and ferulic acid, and the relationship with the precursors was confirmed.

\section{Correlations with chemical parameters}

In Table 2 are presented the chemical parameters of wine samples, while in Figure 1 are shown the possible correlations between these parameters and the presence of Brettanomyces/Dekkera or concentrations of ethylphenols. Among the tested chemical parameters, only free and total $\mathrm{SO}_{2}$, alcohol, and volatile acidity correlated with counts of Brettanomyces/Dekkera or concentrations of ethylphenols. The average concentration of free $\mathrm{SO}_{2}$ was low $(37.3 \%$ of samples), which is indicating a permissive condition for microbial growth. Most of these samples showed high levels of ethylphenols (Figure 1b) and counts of Brettanomyces/Dekkera (Figure 1c), which explains the correlation between 4-ethylphenol and free and total $\mathrm{SO}_{2}$ $\left(r_{s}=-0.177\right.$ and -0.176 , respectively). A free $\mathrm{SO}_{2}$ content of 30 to $40 \mathrm{mg} / \mathrm{L}$ (Gerbaux et al., 2000; Ribéreau-Gayon et al., 2003 ) is necessary for the total elimination of viable populations of Brettanomyces/Dekkera, and even higher doses of $\mathrm{SO}_{2}$ are required in wines with high values of $\mathrm{pH}(\mathrm{Su}-$ draut and Chauvet, 1985). According to Henick-Kling et al. (2000), the wine should be maintained with at least $0.8 \mathrm{mg} / \mathrm{L}$ of molecular $\mathrm{SO}_{2}$ in order to avoid the development of Brettanomyces/Dekkera. It is known that the fraction of free $\mathrm{SO}_{2}$ in bottled wines decreases with storage time due to reactions with organic compounds and oxidation, which may explain some of the low values of free $\mathrm{SO}_{2}$ measured in this research. Notwithstanding, the total $\mathrm{SO}_{2}$ levels were also low (below $20 \mathrm{mg} / \mathrm{L}$ ) in $16 \%$ of samples, which suggests that the addition of this preserving agent was carried out only once during production, leaving these wines unprotected against microbial deterioration.

The amount of alcohol weakly correlated $\left(r_{s}=-0.282\right)$ with the counts of Brettanomyces/Dekkera, although most samples with high counts had up to $13 \%$ (volume fraction) of alcohol (Figure 1d), which has been suggested by some 
Table 2 - Chemical parameters of 126 samples of Brazilian red wines.

\begin{tabular}{|c|c|c|c|c|}
\hline & Minimal & Maximal & Average \pm SD & $\mathrm{CV}(\%)$ \\
\hline Total $\mathrm{SO}_{2}(\mathrm{mg} / \mathrm{L})$ & 3.07 & 137.43 & $50.36 \pm 28.92$ & 57.43 \\
\hline Free $\mathrm{SO}_{2}(\mathrm{mg} / \mathrm{L})$ & 0 & 29.63 & $6.53 \pm 6.73$ & 103.01 \\
\hline $\mathrm{pH}^{\dagger}$ & 3.4 & 4.04 & $3.73 \pm 0.13$ & 3.42 \\
\hline Alcohol (\% vol.) & 10.83 & 14.05 & $12.64 \pm 0.66$ & 5.25 \\
\hline Total dry extract $(\mathrm{g} / \mathrm{L})$ & 22.52 & 38.78 & $29.51 \pm 2.69$ & 9.13 \\
\hline Residual sugar (g/L) & 1.1 & 6.7 & $3.94 \pm 1.22$ & 30.94 \\
\hline Volatile acidity $(\mathrm{g} / \mathrm{L})$ & 0.65 & 1.17 & $0.90 \pm 0,11$ & 12.49 \\
\hline Total $\operatorname{acidity}^{\dagger}(\mathrm{g} / \mathrm{L})$ & 4.56 & 7.33 & $5.84 \pm 0.49$ & 8.38 \\
\hline
\end{tabular}

$\mathrm{CV}$, coefficient of variation; volatile acidity as $\mathrm{g}$ acetic acid/L; total acidity as $\mathrm{g}$ tartaric acid/L. ${ }^{\dagger}$ The acidity of the wines decreased by freezing of the samples, so the $\mathrm{pH}$ values are approximately 0.11 above the actual values.

authors to be the minimal concentration showing inhibitory properties (Froudiére and Larue, 1988; Chatonnet et al., 1993; Rodrigues et al., 2001; Dias et al., 2003; Silva et al., 2004).

Regression plots showed that the highest counts of Brettanomyces/Dekkera and concentrations of ethylphenols were found in samples in the range of 5.5 to $6.7 \mathrm{~g}$ tartaric acid/L total acidity.

The volatile acidity of wines was high (Table 2 ), if the sensorial perception threshold of 0.6 to $0.9 \mathrm{~g} / \mathrm{L}$ is considered (Ough and Amerine, 1988). Twenty-three samples had volatile acidity above $1 \mathrm{~g} / \mathrm{L}$, which is detrimental to the aroma of wine. In general, the production of acetic acid by Brettanomyces/Dekkera is related to the concentration of sugar in the medium (Ciani and Ferraro, 1997; Dias et al., 2003; Abbott et al., 2005; Romano et al., 2008; Vigentini et $a l ., 2008)$. It was found a weak correlation $\left(r_{\mathrm{s}}=0.193\right)$ between volatile acidity and Brettanomyces/Dekkera counts, but the production of acetic acid by this yeast can not be discharged, because of the high residual sugar of samples.

Brazilian legislation establishes that the maximal level of residual sugar in wine to be defined as "dry wine" should not exceed $5 \mathrm{~g} / \mathrm{L}$, while a more restrict definition of dry wine, obtained by the complete fermentation of sugars, should not contain more than $1 \mathrm{~g} / \mathrm{L}$ of residual sugars (Ough and Amerine, 1988). Twenty-three samples (18.25\%) showed levels of sugars above $5 \mathrm{~g} / \mathrm{L}$ (Table 2) suggesting that these samples were susceptible to microbial contamination. Sugar levels of $300 \mathrm{mg} / \mathrm{L}$ are considered high enough to allow the development of ethylphenols in concentrations corresponding to the perception threshold (Chatonnet et al., 1995). Silva et al. (2004) observed that residual sugar concentrations in the range of 0.1 to $12 \%$ did not show any influence on the specific growth rates of $B$. bruxellensis ISA 1791 in mineral medium containing glucose as the sole carbon and energy source. These data suggest a lack of relationship between the residual sugar and ethylphenols concentrations, which was also observed in this work.

\section{Presence of Brettanomyces/Dekkera and ethylphenols correlated to the storage of wine in oak} barrels

Wine samples were tested in order to investigate whether there was any effect correlated to the use of barrels during the maturation of wine on the presence of Brettanomyces/Dekkera and ethylphenols. Table 3 presents the results for samples that were matured in wood barrels. Surprisingly, higher counts of Brettanomyces/Dekkera were found for wines that were not matured, when compared with wine samples that were stored in barrels. However, the concentrations of ethylphenols were not statistically different between the two groups of samples. Wines spoilage by Brettanomyces/Dekkera has been associated with long times of maturation in wood barrels, which presents a number of factors that contribute to the contamination (oxygen, wood porosity, small volume, etc.) (Suárez et al., 2007), but as it has been observed by some authors (Rodrigues et al., 2001; Pérez-Prieto et al., 2003; Coulo et al., 2010), the problem associated with the presence of this yeast is much more complex. The development of Brettanomyces/Dekkera and production of ethylphenols is influenced by the practices of vinification (Chatonnet et al., 1992, 1995) and wine storage time (Pérez-Prieto et al., 2003), which may be related to the results obtained. Brazil-

Table 3 - Mean Brettanomyces/Dekkera counts and ethylphenols concentrations correlated to the stage of the wine in oak barrels.

\begin{tabular}{lcc}
\hline & $\begin{array}{c}\text { With barrel } \\
\text { maturation }\end{array}$ & $\begin{array}{c}\text { Without barrel } \\
\text { maturation }\end{array}$ \\
\hline $\begin{array}{l}\text { Number of samples }(n) \\
\text { Positive for }\end{array}$ & 39 & 32 \\
Brettanomyces/Dekkera & 8 & 14 \\
$\begin{array}{l}\text { Brettanomyces/Dekkera } \\
\text { (CFU/mL)* }\end{array}$ & $9.91 \pm 35.94$ & $261.52 \pm 586.24$ \\
4-ethylphenol $(\mu \mathrm{g} / \mathrm{L})$ & $610.66 \pm 761.24$ & $495.13 \pm 407.30$ \\
4-ethylguaiacol $(\mu \mathrm{g} / \mathrm{L})$ & $65.84 \pm 52.09$ & $59.08 \pm 32.06$ \\
\hline
\end{tabular}

*Different by t-test $(\mathrm{p}=0.021)$. 
ian wineries using oak barrels on a large scale are still very few, due to the high costs of these barrels. Thus, it appears that the use of wood barrels in a small-scale production facility and shorter maturation times have favored greater care, compared with storage in stainless steel or concrete tanks, consequently reducing contaminations.

\section{Presence of Brettanomyces/Dekkera as a function of grape variety}

In this research, the presence of Brettanomyces/Dekkera was not found to be correlated with the variety of grape used in the wine making (Table 4), even though the Cabernet Sauvignon varieties were slightly more prone to microbial spoilage than the Merlot samples due to the characteristics of their $\mathrm{pH}$ and total dry extract. However, there were no statistical differences for Brettanomyces/Dekkera counts between the two varieties, suggesting very similar winemaking practices for both varietals. The ratio of 4-ethylphenol and 4-ethylguaiacol was higher for Cabernet Sauvignon, which is linked to higher concentrations of $p$-coumaric acid (Pollnitz et al., 2000), with values similar to those found by others authors: 10:1 for Cabernet Sauvignon and 8:1 for Merlot (Pollnitz et al., 2000); 8:1 for Bordeaux red wines (Chatonnet et al., 1992); and around 9:1 for 180 different Chilean wines (Majcenovic, 2003).

\section{Conclusion}

The prevalence of Brettanomyces/Dekkera and the concentrations of ethylphenols in the investigated Brazilian

Table 4 - Presence of Brettanomyces/Dekkera and chemical parameters of the wines as a function of grape variety.

\begin{tabular}{lcc}
\hline & $\begin{array}{c}\text { Cabernet } \\
\text { Sauvignon }\end{array}$ & Merlot \\
\hline $\begin{array}{l}\text { Brettanomyces/Dekkera } \\
(\mathrm{CFU} / \mathrm{mL})\end{array}$ & $26.91 \pm 110.97$ & $59.49 \pm 224.57$ \\
4-ethylphenol $(\mu \mathrm{g} / \mathrm{L})$ & $628.71 \pm 758.50$ & $553.45 \pm 556.87$ \\
4-ethylguaiacol $(\mu \mathrm{g} / \mathrm{L})$ & $65.60 \pm 52.77$ & $65.88 \pm 50.99$ \\
Ratio 4-EP/4-EG* & $9.24 \pm 4.46$ & $7.51 \pm 3.73$ \\
pH $^{*}$ & $3.78 \pm 0.11$ & $3.68 \pm 0.11$ \\
Total acidity $(\mathrm{g}$ tartaric acid/L)* & $5.96 \pm 0.41$ & $5.76 \pm 0.53$ \\
Volatile acidity $(\mathrm{g}$ acetic & $0.93 \pm 0.11$ & $0.87 \pm 0.10$ \\
acid/L)* & $30.33 \pm 2.16$ & $28.76 \pm 2.90$ \\
Total dry extract $(\mathrm{g} / \mathrm{L}) *$ & $49.72 \pm 25.19$ & $51.67 \pm 31.61$ \\
Total $\mathrm{SO}_{2}(\mathrm{mg} / \mathrm{L})$ & $6.67 \pm 6.56$ & $5.99 \pm 6.26$ \\
Free $\mathrm{SO}_{2}(\mathrm{mg} / \mathrm{L})$ & $12.60 \pm 0.66$ & $12.67 \pm 0.65$ \\
Alcohol $(\% \mathrm{v} / \mathrm{v})$ & $4.12 \pm 1.32$ & $3.95 \pm 1.02$ \\
\hline Residual sugar $(\mathrm{g} / \mathrm{L})$ &
\end{tabular}

*Different by t-test $(\mathrm{p}<0.05)$ : ratio 4-EP/4-EG $(\mathrm{p}=0.03) ; \mathrm{pH}(\mathrm{p}=5.33 \mathrm{x}$ $\left.10^{-6}\right)$; total acidity $(\mathrm{p}=0.02)$; volatile acidity $(\mathrm{p}=0.002)$; total dry extract $(\mathrm{p}=0.001)$. red wines were similar to those found for wines from other countries. The levels of contamination could be considered high, if the possible impact on sensorial aspects is taken into account. The levels of $\mathrm{SO}_{2}$ showed to be the determinant condition for microbial spoilage, since the growth of Brettanomyces/Dekkera was dependent on the levels of $\mathrm{SO}_{2}$ and alcohol, but it seemed not to be influenced by variations in sugar, acidity and total dry extract. Despite of a well-established correlation, ethylphenols were more frequent than Brettanomyces/Dekkera in the investigated samples, and the results showed that the stage in barrels and grape varieties did not influence the levels of contamination and concentrations of ethylphenols.

\section{Acknowledgments}

The authors wish to thank Dr. Paulo Gustavo Celso of the National Agricultural Laboratory (LANAGRO, RS, Brazil) for his collaboration in this work. The authors acknowledge the financial support of CAPES (Brazil) for the first author's scholarship.

\section{References}

Abbott DA, Hynes SH, Ingledew WM (2005) Growth rates of Dekkera/Brettanomyces yeasts hinder their ability to compete with Saccharomyces cerevisiae in batch corn mash fermentations. Appl Microbiol Biotechn 66:641-647.

Barata A, Caldeira J, Botelheiro R, Pagliara D, Malfeito-Ferreira M, Loureiro V (2008) Survival patterns of Dekkera bruxellensis in wines and inhibitory effect of sulphur dioxide. Int J Food Microbiol 121:201-207.

Chatonnet P, Boidron J, Pons M (1990) Elevage des vins rouges en fûts de chêne: Évolution de certains composés volatils et de leur impact arômatique. Sci Alim 10:565-587.

Chatonnet P, Dubourdieu D, Boidron N (1995) The influence of Brettanomyces/Dekkera sp. yeasts and lactic bacteria on the ethylphenol content of red wines. Am J Enol Vitic 46:463468.

Chatonnet P, Dubourdieu D, Boidron JN, Lavigne V (1993) Synthesis of volatile phenols by Saccharomyces cerevisiae in wines. J Sci Food Agric 62:191-202.

Chatonnet P, Dubourdieu D, Boidron JN, Pons M (1992) The origin of ethylphenols in wines. J Sci Food Agric 60:165-178.

Chatonnet P, Viala C, Dubourdieu D (1997) Influence of polyphenolic components of red wines on the microbial synthesis of volatile phenols. Am J Enol Vitic 48:443-448.

Ciani M, Ferraro L (1997) Role of oxygen on acetic acid production by Brettanomyces/Dekkera in winemaking. J Sci Food Agric 75:489-495.

Coulon J, Perello MC, Lonvaud-Funel A, Revel G, Renouf V (2010) Brettanomyces bruxellensis evolution and volatile phenols production in red wines during storage in bottles. $\mathrm{J}$ Appl Microbiol 108:1450-1458.

Couto JA, Campos FM, Figueiredo AR, Hogg TA (2006) Ability of Lactic Acid Bacteria to Produce Volatile Phenols. Am J Enol Vitic 57:166-171.

Di Stefano R (1985) The ethyl phenols in wines. Vignevini 12:35-38. 
Dias L, Pereira-Da-Silva S, Tavares M, Malfeito-Ferreira M, Loureiro V (2003) Factors affecting the production of 4-ethylphenol by the yeast Dekkera bruxellensis in enological conditions. Food Microbiol 20:377-384.

Edlin DAN, Narbad A, Dickinson JR, Lloyd D (1995) The biotransformation of simple phenolic compounds by Brettanomyces anomalus. FEMS Microbiol Lett 125:311-316.

Froudiére I, Larue F (1988) Conditions de survie de Brettanomyces (Dekkera) dans le moût de raisin et le vin. Conn Vigne Vin 2:296-303.

Fugelsang KC, Edwards CG (2007) Wine Microbiology: Practical Applications and Procedures. 2th ed. Springer, New York, $413 \mathrm{pp}$.

Fugelsang KC, Zoecklein BW (2003) Population dynamics and effects of Brettanomyces bruxellensis strains on Pinot Noir (Vitis vinifera L.) wines. Am J Enol Vitic 54:294-300.

Gerbaux V, Jeudy S, Monamy C (2000) Etude des phénols volatils dans les vins de Pinot noir en Bourgogne. Bull OIV 73:581599.

Gerbaux V, Vincent B, Bertrand A (2002) Influence of maceration temperature and enzymes on the content of volatile phenols in Pinot noir wines. Am J Enol Vitic 53:131-137.

Gerós H, Cássio F, Leão C (2000) Utilization and transport of acetic acid in Dekkera anomala and their implications on the survival of the yeast in acidic environments. J Food Prot 63:96-101.

Heimoff S (1996) Brett study yields surprises. Wine Business Monthly 3:37-40.

Henick-Kling T, Egli C, Licker J, Mitrakul C, Acree TE (2000) Brettanomyces in wine. In: Fifth Int. Symp. Cool Climate Vitic. Oenol. Winetitles, Melbourne, pp 1-7.

Henschke P, Bellon J, Capone D, Coulter A, Cowey G, Cozzolino D, Curtin C, Field J, Gishen M, Graves P, Latey K, Robinson E, Francis IL, Lopes MB, Godden P (2004) Incidence and control of Brettanomyces: The Australian perspective. Am J Enol Vitic 55:304-A.

Heresztyn T (1986) Metabolism of phenolic compounds from hydroxycinnamic acids by Brettanomyces yeasts. Arch Microbiol 146:96-98.

Ibeas JI, Lozano I, Perdigones F, Jimenez J (1996) Detection of Dekkera/Brettanomyces strains in sherry by a Nested PCR method. Appl Environm Microbiol 62:998-1003.

Joseph CML, Bisson L (2004) Physiological diversity of Brettanomyces/Dekkera isolated from wine. Am J Enol Vitic, 55:302-A.

Lauritsen FR, Nielsen LT, Degn H, Lloyd D, Bohatka S (1991) Identification of dissolved volatile metabolites in microbial cultures by membrane inlet tandem mass-spectrometry. Biol Mass Spectrom 20:253-258.

López R, Aznar M, Cacho J, Ferreira V (2002) Determination of minor and trace volatile compounds in wine by solid-phase extraction and gas chromatography with mass spectrometric detection. J Chromat A 966:167-177.

Majcenovic AB (2003) Etilfenoles como indicadores de la actividad de Brettanomyces. In: IX Congr. Latinoamer. Vitic. Enol. Pontificia Universidad Católica de Chile, Santiago, pp 205.
Malfeito-Ferreira M, Laureano P, Barata A, D'antuono I, Stender H, Loureiro V (2004) Effect of different barrique sanitation procedures on yeasts isolated from the inner layers of wood. Am J Enol Vitic 55:304-A.

Millet V, Lonvaud-Funel A (2000) The viable but non-culturable state of wine microorganisms during storage. Lett Appl Microbiol 30:136-141.

Nikfardjam MP, May B, Tschiersch C (2009) 4-ethylphenol and 4-ethylguaiacol contents in bottled wines from the German 'Württemberg' region. Eur Food Res Technol 230:333-341.

Ough CS, Amerine MA (1988) Methods for Analysis of Musts and Wines. $2^{\text {th }}$ ed. John Wiley \& Sons, New York, 400 pp.

Pérez-Prieto LJ, López-Roca JM, Martínez-Cutillas A, PardoMínguez F, Gómez-Plaza E (2003) Extraction and formation dynamic of oak-related volatile compounds from different volume barrels to wine and their behavior during bottle storage. J Agric Food Chem 51:5444-5449.

Pollnitz AP, Pardon KH, Sefton MA (2000) Quantitative analysis of 4-ethylphenol and 4-ethylguaiacol in red wine. J Chromat A 874:101-109.

Ribéreau-Gayon P, Glories Y, Maujean A, Dubourdieu D (2003) Tratado de Enología: Química del Vino, Estabilización y Tratamientos. v. 2. Hemisfério Sur, Buenos Aires, 537 pp.

Rivas B, Rodríguez H, Curiel JA, Landete JA, Muñoz R (2009) Molecular screening of wine lactic acid bacteria degrading hydroxycinnamic acids. J Agric Food Chem 57:490-494.

Rodrigues N, Gonçalves G, Pereira-Da-Silva S, Malfeito-Ferreira M, Loureiro V (2001) Development and use of a new medium to detect yeasts of the genera Dekkera/Brettanomyces. J Appl Microbiol 90:588-599.

Romano A, Perello MC, De Revel G, Lonvaud-Funel A (2008) Growth and volatile compound production by Brettanomyces/Dekkera bruxellensis in red wine. J Appl Microbiol 104:1577-1585.

Romano A, Perello MC, Lonvaud-Funel A, Sicard G, De Revel G (2009) Sensory and analytical re-evaluation of "Brett character". Food Chem 114:15-19.

Silva P, Cardoso H, Gerós H (2004) Studies on the wine spoilage capacity of Brettanomyces/Dekkera spp. Am J Enol Vitic 55:65-72.

Smith MT (1998) Brettanomyces Kufferath and van Laer. In: Kurtzman CP, Fell JW (eds) The Yeasts. 4th ed. Elsevier, New York, pp 450-453.

Suárez R, Suárez-Lepe JA, Morata A, Calderón F (2007) The production of ethylphenols in wine by yeasts of the genera Brettanomyces and Dekkera: A review. Food Chem 102:10-21.

Sudraut P, Chauvet S (1985) Activité antilevure de l'anhydride sulfureux moléculaire. J Int Sci Vigne Vin 19:31-40.

Vigentini I, Romano A, Compagno C, Merico A, Molinari F, Tirelli A, Foschino R, Volonterio G (2008) Physiological and oenological traits of different Dekkera/Brettanomyces bruxellensis strains underwine-model conditions. FEMS Yeast Res 8:1087-1096.

All the content of the journal, except where otherwise noted, is licensed under a Creative Commons License CC BY-NC. 